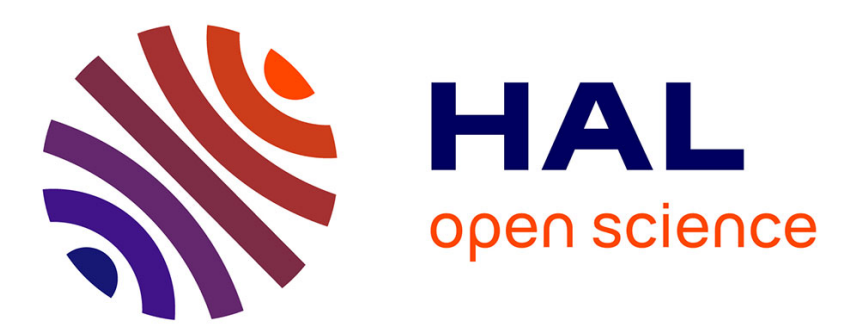

\title{
Diagnosing phosphorus status of natural grassland in the presence of white clover
}

Claire Jouany, Pablo Cruz, Patrick Petibon, Michel M. Duru

\section{To cite this version:}

Claire Jouany, Pablo Cruz, Patrick Petibon, Michel M. Duru. Diagnosing phosphorus status of natural grassland in the presence of white clover. European Journal of Agronomy, 2004, 21 (3), pp.273-285. 10.1016/j.eja.2004.06.001 . hal-02678640

\section{HAL Id: hal-02678640 \\ https://hal.inrae.fr/hal-02678640}

Submitted on 31 May 2020

HAL is a multi-disciplinary open access archive for the deposit and dissemination of scientific research documents, whether they are published or not. The documents may come from teaching and research institutions in France or abroad, or from public or private research centers.
L'archive ouverte pluridisciplinaire HAL, est destinée au dépôt et à la diffusion de documents scientifiques de niveau recherche, publiés ou non, émanant des établissements d'enseignement et de recherche français ou étrangers, des laboratoires publics ou privés. 


\title{
Diagnosing phosphorus status of natural grassland in the presence of white clover
}

\author{
Claire Jouany*, Pablo Cruz, Patrick Petibon, Michel Duru \\ UMR ARCHE, INRA, BP 27, 31326 Castanet-Tolosan, France
}

Received 2 January 2003; received in revised form 8 March 2004; accepted 10 June 2004

\begin{abstract}
The phosphorus nutrition index (PNI) method proved to be suitable for diagnosing $\mathrm{P}$ nutrition level over a wide range of grass swards. It is based on relative nutrient concentrations and relies on a critical curve for optimum $\mathrm{P}$ concentration which is a function of sward $\mathrm{N}$ concentration. The objectives of this paper were to verify to what extent this method was valid for $\mathrm{P}$ nutrition diagnosis when white clover was present in the sward in view of the fact that white clover $\mathrm{N}$ concentration is frequently reported to be much higher than that of grass and to remain constant whatever the amount of biomass produced.

For this purpose we analysed the effect of $\mathrm{N}$ addition on $\mathrm{N}$ and $\mathrm{P}$ concentrations in white clover and rye grass grown in pure stands with unlimited P supply in a garden collection and compared it with clover behaviour in a field experiment on a natural grassland with a similar P status.

Clover displayed a different affinity for $\mathrm{P}$ according to whether it grew in a pure or mixed sward. In a pure stand, we observed a very significant effect of $\mathrm{N}$ on $\mathrm{N}$ and $\mathrm{P}$ concentrations measured in individual organs and whole plants; the highest $\mathrm{N}$ concentrations were measured in clover. This species behaved differently from ryegrass: for a given level of $\mathrm{N}$ supply, plant $\mathrm{N}$ concentration decreased when petioles were added to the laminae samples, while $\mathrm{P}$ concentrations remained constant; for rye grass both $\mathrm{N}$ and $\mathrm{P}$ concentrations decreased when sheaths were added to laminae. Clover in mixed swards had a lower $\mathrm{P}$ nutritional status than when grown in a pure stand, due to its lower capacity to compete with grasses for light capture and $\mathrm{P}$ acquisition.

Analysis of data from the literature demonstrated that differences in response between clover and grass were more pronounced under limited $\mathrm{P}$ supply, when clover displayed a lower ability than grasses to adjust $\mathrm{P}$ concentration to that of $\mathrm{N}$ due to its lower capacity to adapt to low $\mathrm{P}$ availability. As a consequence it became even less competitive.

We concluded that there are limitations to the use of nutrient diagnosis systems based on relative concentrations when the herbage contains a large proportion of white clover and proposed that only the non-clover fraction should be used for diagnosis to avoid excessive $\mathrm{P}$ application when PNIs are used for fertiliser recommendations.
\end{abstract}

(c) 2004 Elsevier B.V. All rights reserved.

Keywords: Diagnosis; Grassland; Nutrition index; Phosphorus; White clover

\section{Introduction}

* Corresponding author. Tel.: +33 561 285020; fax: +33561735537 .

E-mail address: cjouany@ toulouse.inra.fr (C. Jouany).
In most temperate areas, sustainable management of grassland ecosystems has to deal with evaluation and 
management of phosphorus $(\mathrm{P})$, which is the second nutrient limiting production after nitrogen $(\mathrm{N})$ (Aerts and Chapin, 2000). Within the general context of environmental and economic concerns, accurate management of mineral resources becomes a priority: $\mathrm{P}$ fertilisation is not always required, the aim being to match the amount of $\mathrm{P}$ supplied from the soil with plant demand, which is mainly governed by the rate of fertiliser N (Whitehead, 1995). In these situations, advisory services recommend the exploitation of accumulated $\mathrm{P}$ in surface soil layers built up over the years from organic or mineral inputs applied in the seventies (Tunney et al., 1997) instead of fertiliser application.

For this purpose, appropriate diagnostic systems are needed in order to manage fertilisation accordingly. Methods based on nutrient concentration ratios in plant tissues have been developed for alfalfa (Walworth et al., 1986) and perennial ryegrass swards (Bailey et al., 1997a, 2000). These approaches are more reliable than those based on a single critical concentration, which varies with crop age and with the concentrations of other nutrients (Pinkerton and Randall, 1994) as a consequence of mineral dilution in the process of biomass accumulation. For $\mathrm{N}$, a critical curve has been proposed which gives the optimum $\mathrm{N}$ concentration for different levels of biomass accumulation in swards and serves for diagnostic purposes: for a given sward biomass, a nitrogen nutrition index (NNI) is defined as the ratio of measured $\mathrm{N}$ concentration to its respective optimum value obtained from the critical curve expressed in percent $\mathrm{N}$ (Lemaire et al., 1989).

For P however, Duru and Thélier-Huché (1997) demonstrated that there is no single critical curve as found for $\mathrm{N}$, since the variation in optimum $\mathrm{P}$ concentration during sward growth is dependent on the $\mathrm{N}$ application rate. So the critical $\mathrm{P}$ concentration of the plant cannot be determined independently from its $\mathrm{N}$ concentration. Consequently, Duru and Thélier-Huché (1997) proposed the following relationship: $\mathrm{P} \%_{\text {optimum }}$ $=0.15+0.065 \mathrm{~N} \%_{\text {measured }}$, which provides at a given time, the minimal $\mathrm{P}$ concentration in sward needed to produce maximum dry matter as a function of its $\mathrm{N}$ concentration. This relationship remains linear within the range of $\mathrm{N}$ and $\mathrm{P}$ concentrations observed in grasslands. Duru and Ducrocq (1997) calculated phosphorus nutrition index (PNI) as the ratio of $\mathrm{P} \%$ measured in the given sward to $\mathrm{P} \%_{\text {optimum }}$ obtained with the crit- ical curve, expressed in percent. In practice indices vary between values above 100 (signifying an adequate or excessive P level) to below 60 (indicating severe P deficiency). Duru and Ducrocq (1997) applied this method to diagnose a set of natural swards with severe $\mathrm{P}$ deficiency and showed that this index gives an accurate diagnosis of the $\mathrm{P}$ nutrition level during growth, albeit after the event. In practice, index values are used by extension services to make fertiliser recommendations (Thélier-Huché et al., 1999).

However, the question remains as to what extent this approach can be used to diagnose $\mathrm{P}$ nutrition level for mixed swards where white clover $\mathrm{N}$ concentration is much higher than that of the grass fraction (Mackay et al., 1995) and remains constant whatever the amount of biomass produced (Sinclair et al., 1996). In order to answer this question, we verified under non-limiting $\mathrm{P}$ supply first for pure stands then for a mixed sward, whether or not white clover is able to adjust $\mathrm{P}$ concentration to its $\mathrm{N}$ concentration with the same relationship as for grasses. Lots of references exist on mixed swards containing white clover, but few data are available on clover itself in pure or mixed swards.

Our objectives were: (i) to evaluate, under non-limiting $\mathrm{P}$ supply, the effect of $\mathrm{N}$ addition on $\mathrm{N}$ and $\mathrm{P}$ concentrations of clover and rye grass grown in pure stands. For this purpose analyses have been performed on separate organs (laminae and petioles, laminae and sheaths); (ii) to analyse white clover response to $\mathrm{N}$ in mixed swards and compare it with data obtained from pure stands; (iii) to evaluate the validity of the PNI method in the presence of white clover, by comparing indices measured on mixed swards and those obtained for clover-free stands, within a wide range of clover contents.

This work relied on two experimental fields: a garden collection and a long term field experiment set up on a natural grassland, where fertilisation treatments have differentiated a wide range of white clover contents.

\section{Materials and methods}

\subsection{Pure stands}

The garden collection was set up on an experimental field located in Auzeville, France $\left(1^{\circ} 43^{\prime} \mathrm{E}\right.$, 
$\left.43^{\circ} 5^{\prime} \mathrm{N}\right)$. The altitude is $150 \mathrm{~m}$ above sea level; annual mean precipitation is $700 \mathrm{~mm}$ and temperature $13^{\circ} \mathrm{C}$. The soil, a clayey loam is a fluvisol developed on molasse sediments, a tertiary deposit coming from the Pyrénées. Its $\mathrm{pH}_{\text {water }}(0-10 \mathrm{~cm})$ was 8.0 ; organic matter content $16 \mathrm{mg} \mathrm{kg}^{-1}$ soil; total $\mathrm{N}$ concentration $1.0 \mathrm{mg} \mathrm{kg}^{-1}$ soil; available $\mathrm{P}$ concentration $50 \mathrm{mg} \mathrm{kg}^{-1}$ soil (Olsen et al., 1954) and total P concentration $0.65 \mathrm{~g} \mathrm{~kg}^{-1}$ soil.

Rye grass and clover pure stands were sown in November 2000. The experimental design was chosen to study the effects of $\mathrm{N}$ supplied as two treatments with a non-limiting P supply: NOP1 and N1P1, where 0: nil and $\mathrm{N} 1: 100 \mathrm{~kg} \mathrm{ha}^{-1} \mathrm{a}^{-1}$, supplied as $\mathrm{NH}_{4} \mathrm{NO}_{3}$ for the first and second growth cycles; an ample supply of $\mathrm{P}$ was provided, $250 \mathrm{~kg} \mathrm{ha}^{-1} \mathrm{a}^{-1}$, as monocalcium phosphate at the beginning of spring growth, as well as $\mathrm{K}\left(250 \mathrm{~kg} \mathrm{ha}^{-1} \mathrm{a}^{-1}\right.$, as potassium chloride). Ample water was provided through irrigation. The plots $(1 \mathrm{~m}$ $\times 1 \mathrm{~m}$ ) were arranged in three randomised blocks; each data value represents the mean of three replications.

Rye grass and white clover were hand-harvested during the second cycle, on 10 May 2003; for rye grass biomass harvested on $0.1 \mathrm{~m}^{2}$ was sorted between laminae and sheaths, for white clover 25 laminae and their petioles were sampled per plot. Laminae and petioles, as well as sheaths and laminae were separated with a blade; clover stolons were not sampled.

\subsection{Mixed stands}

The field trial was established on a permanent pasture located in the southern Massif Central at Gramond, France $\left(2^{\circ} 23^{\prime} \mathrm{E}^{\circ} ; 44^{\circ} 14^{\prime} \mathrm{N}\right)$. The altitude is $607 \mathrm{~m}$ above sea level, average annual precipitation is $960 \mathrm{~mm}$ and annual mean temperature is $6.9^{\circ} \mathrm{C}$. The soil, a sandy loam, is a luvisol developed on mica schist. Its $\mathrm{pH}_{\mathrm{water}}(0-10 \mathrm{~cm})$ was 5.3 ; organic matter content $47.1 \mathrm{mg} \mathrm{kg}^{-1}$ soil; total $\mathrm{N}$ concentration $2.53 \mathrm{mg} \mathrm{kg}^{-1}$ soil; extractable P $44 \mathrm{mg} \mathrm{kg}^{-1}$ soil (Olsen et al., 1954) and total $\mathrm{P}$ concentration $0.8 \mathrm{~g} \mathrm{~kg}^{-1}$ soil. This soil exhibits features characteristic of a permanent grassland, with high organic matter and $\mathrm{N}$ contents and large $\mathrm{P}$ reserves ascribed to frequent basic slag inputs in the 1970s. Before the experiment started, two hay cuts were taken each year in spring and autumn and the field had received no mineral fertiliser for the last 10 years.

At the outset of the experiment in 1998, white clover estimated with the quadrat points method (Brown, 1954), represented $7.9 \%$ of the total species present in the grassland.

The experimental design was chosen to study under frequent defoliation, the effects of $\mathrm{N}$ and $\mathrm{P}$ supplied as 4 treatments, NOP0, NOP1, N1P0 and N1P1, where 0: nil, P1: $50 \mathrm{~kg} \mathrm{ha}^{-1} \mathrm{a}^{-1}$ supplied as monocalcium phosphate at the beginning of spring growth; $\mathrm{N} 1=100 \mathrm{~kg} \mathrm{ha}^{-1} \mathrm{a}^{-1}$ and $50 \mathrm{~kg} \mathrm{ha}^{-1} \mathrm{a}^{-1}$, supplied as $\mathrm{NH}_{4} \mathrm{NO}_{3}$, for spring growth and summer re-growth, respectively. A uniform application of $400 \mathrm{~kg} \mathrm{Kha}^{-1} \mathrm{a}^{-1}$, supplied as $\mathrm{KCl}$, and $1000 \mathrm{~kg}$ $\mathrm{CaO} \mathrm{ha}^{-1} \mathrm{a}^{-1}$ was given to all plots in order to maintain unlimited $\mathrm{K}$ supply to the sward and prevent acidification of the soil. The plots $(4 \mathrm{~m} \times 5 \mathrm{~m})$ were arranged in four randomised blocks; each data value is the mean of four replications.

Plots were cut three times a year for the four treatments; an extra NOP0 treatment was added with different cutting regimes: two cuts per year, the first cut for spring growth being omitted.

The data analysed were obtained on the spring growth and summer re-growth, representing at least $70 \%$ of the total annual production for the years 1998 , 1999 and 2000. For 1999 and 2000, the first cut took place in late April or early May, with another 6 weeks later. Dry matter yield was measured on each plot by cutting the sward within a $0.25 \mathrm{~m} \times 0.75 \mathrm{~m}$ quadrat with edging shears.

In 1998, autumn re-growth showed significant white clover invasion, so biomass samples taken after this were sorted into two fractions: non-white clover and white clover. For clover, stolons were always absent from the biomass harvested. Bulk samples or fractions were oven dried at $80^{\circ} \mathrm{C}$ for $48 \mathrm{~h}$; white clover contribution to the total biomass was calculated and expressed as a percentage on a weight basis.

\subsection{Measurements}

Total $\mathrm{P}$ concentration was determined on oven dried $\left(80^{\circ} \mathrm{C}\right)$ ground milled herbage $(0.5 \mathrm{~mm})$ after wet digestion in $\mathrm{H}_{2} \mathrm{SO}_{4}-\mathrm{H}_{2} \mathrm{O}_{2}$ using the malachite green method (Van Veldhoven and Mannaerts, 1987). 
Total $\mathrm{N}$ concentration was determined with a $\mathrm{CN}$ gas analyser (LECO Corporation, St. Joseph, MI, USA).

For pure stand samples, analysis were performed on separated organs: folioles and petioles for clover, laminae and sheaths for ryegrass. For Gramond samples, total $\mathrm{N}$ and $\mathrm{P}$ concentrations were measured on both fractions (clover and non-clover) at all dates for N0 treatments and only two dates out of five for plots given $\mathrm{N}$, since the amount of clover was too low for measuring both $\mathrm{N}$ and $\mathrm{P}$ concentrations.

Phosphorus and $\mathrm{N}$ concentrations were measured on each organ or fraction separately then weighted by the relative contributions of each biomass to the total for calculating $\mathrm{N}$ and $\mathrm{P}$ concentrations of the whole plants or mixed swards.

PNIs were calculated according to Duru and Ducrocq (1997) with the following relation:

$\mathrm{PNI}=\left(\frac{\mathrm{P} \%_{\text {measured }}}{\mathrm{P} \%_{\text {optimum }}}\right) \times 100 ; \quad$ with

$\mathrm{P} \%_{\text {optimum }}=0.15+0.065 \mathrm{~N} \%_{\text {measured }}$.

Statistical analysis was performed with Statistix (1996) and comparison of means were carried out with Bonferroni-test.

$\mathrm{P} \%_{\text {optimum }}=0.15+0.065 \mathrm{~N} \%_{\text {measured }}$, which provides at a given time, the minimal $\mathrm{P}$ concentration in sward needed to produce maximum dry matter as a function of its $\mathrm{N}$ concentration. This relationship remains linear within the range of $\mathrm{N}$ and $\mathrm{P}$ concentrations observed in grasslands. Duru and Ducrocq (1997) calculated phosphorus nutrition index as the ratio of $\mathrm{P} \%_{\text {measured }}$ in the given sward to $\mathrm{P} \%_{\text {optimum }}$.

\section{Results}

\section{1. $N$ and $P$ concentrations in pure stands}

We noticed a very significant effect of $\mathrm{N}$ supply on $\mathrm{N}$ and $\mathrm{P}$ concentrations measured for individual organs as well as whole plants $(P<0.001)$. Those concentrations are higher for plots receiving $\mathrm{N}$ (Tables 1 and 2). We also observed a very significant effect of the organ analysed on $\mathrm{N}$ concentrations measured on separated parts, and of species when concentrations were calculated for whole plants $(P<0.001)$. Whatever the treatment, highest $\mathrm{N}$ concentrations were measured on clover plants; within one species and treatment, lowest $\mathrm{N}$ concentrations were measured on sheaths and petioles. There was no effect of organ or species on $\mathrm{P}$ concentrations measured on separate parts or whole plants. In Fig. 1, P concentrations were plotted against $\mathrm{N}$ concentrations for folioles and laminae and whole leaves, i.e. folioles + petioles and laminae + sheaths.

For rye grass, whatever the treatment or fraction analysed, points were positioned above the critical curve, indicating non limiting $\mathrm{P}$ supply during growth. The graph showed that ryegrass was able to adjust $\mathrm{P}$ uptake to $\mathrm{N}$ uptake when $\mathrm{N}$ supply increased between N0 and N1 treatments; co-dilution of P and N took place.

For white clover when folioles only were analysed, the points did not lie on the critical curve, the separation being maximum for the NO treatment. When petioles were added, the experimental points moved closer but remained below the critical curve. This species showed different behaviour from ryegrass: for a given level of $\mathrm{N}$ supply, $\mathrm{N}$ concentration decreased when

Table 1

Nitrogen concentration $\left(\mathrm{mg} \mathrm{g}^{-1}\right.$ dry matter) measured in white clover and ryegrass organs and whole plants

\begin{tabular}{|c|c|c|c|c|c|c|c|}
\hline \multirow[t]{2}{*}{ Treatment } & \multicolumn{2}{|c|}{ Rye grass } & \multicolumn{2}{|c|}{ White clover } & & \multirow[t]{2}{*}{ Ryegrass whole plant } & \multirow[t]{2}{*}{ White clover whole plant } \\
\hline & Sheaths & Laminae & Petioles & Folioles & & & \\
\hline NOP1 & $9.3 \mathrm{a}$ & $16.3 \mathrm{a}, \mathrm{b}$ & $22 \mathrm{a}$ & $46.2 \mathrm{~b}$ & & $14.9 \mathrm{a}$ & $37.5 \mathrm{~b}$ \\
\hline N1P1 & $24.2 \mathrm{~b}$ & $38.6 \mathrm{c}$ & $33.6 \mathrm{a}$ & $54 \mathrm{~b}$ & & $33.6 \mathrm{~b}$ & $46.9 \mathrm{~b}$ \\
\hline $\mathrm{N}$ effect & $* * *$ & & $* * *$ & & $\mathrm{~N}$ effect & $* * *$ & \\
\hline Organ effect & $* * *$ & & $* * *$ & & Species effect & $* * *$ & \\
\hline
\end{tabular}

Figures within one species followed by the same letter are not significantly different by Bonferronni-test $P<0.001$. Significance of N, organ and species effect.

*** $P<0.001$. 
Table 2

Phosphorus concentrations ( $\mathrm{mg} \mathrm{g}^{-1}$ dry matter) measured in white clover and ryegrass whole plants

\begin{tabular}{|c|c|c|c|c|c|c|c|}
\hline \multirow[t]{2}{*}{ Treatment } & \multicolumn{2}{|c|}{ Rye grass } & \multicolumn{2}{|c|}{ White clover } & & \multirow[t]{2}{*}{ Ryegrass whole plant } & \multirow[t]{2}{*}{ White clover whole plant } \\
\hline & Sheaths & Laminae & Petioles & Folioles & & & \\
\hline NOP1 & 2.8 & 3.0 & 3.4 & 3.4 & & 3.0 & 3.4 \\
\hline N1P1 & 4.0 & 4.2 & 4.5 & 4.3 & & 4.1 & 4.3 \\
\hline $\mathrm{N}$ effect & $* * *$ & & $* * *$ & & $\mathrm{~N}$ effect & $* * *$ & \\
\hline Organ effect & NS & & NS & & Species effect & NS & \\
\hline
\end{tabular}

Figures within one species followed by the same letter are not significantly different by Bonferronni-test $P<0.001$. Significance of N, organ and species effect.

*** $P<0.001$; NS: not significant.

petioles were added to the leaf samples, while $\mathrm{P}$ concentrations remained constant.

White clover laminae as well as whole plants (laminae + petioles) were able to adjust their $\mathrm{P}$ concentrations when $\mathrm{N}$ supply increased from $\mathrm{N} 0$ to $\mathrm{N} 1$, but not to the same extent as for ryegrass. These results suggest that white clover was less capable than grasses to adjust $\mathrm{P}$ uptake to its $\mathrm{N}$ concentration.

\section{2. $N$ and $P$ concentrations in mixed swards}

Within mixed swards, white clover content decreased under mineral $\mathrm{N}$ application and cutting regime; maximum contents were observed for the summer re-growth 1999. By the 2000 harvests, white clover had totally disappeared from plots supplied with $\mathrm{N}$ as well as from plots managed with late cuts (Table 3).

Nitrogen and $\mathrm{P}$ concentrations determined on white clover and non-white clover fractions are shown in Tables 4 and 5 . Results indicate a very significant effect of the fraction analysed on $\mathrm{N}$ concentration for the four dates $(P<0.001)$ and a significant effect of added $\mathrm{N}$ at the first harvest. For a given date and treatment, the $\mathrm{N}$ concentration measured on the white clover fraction was always higher than that of the one without clover; the differences were very significant $(P<0.001)$.

\section{$\mathbf{P}$ concentration $\left(\mathrm{mg} \mathrm{g}^{-\mathbf{1}}\right)$}

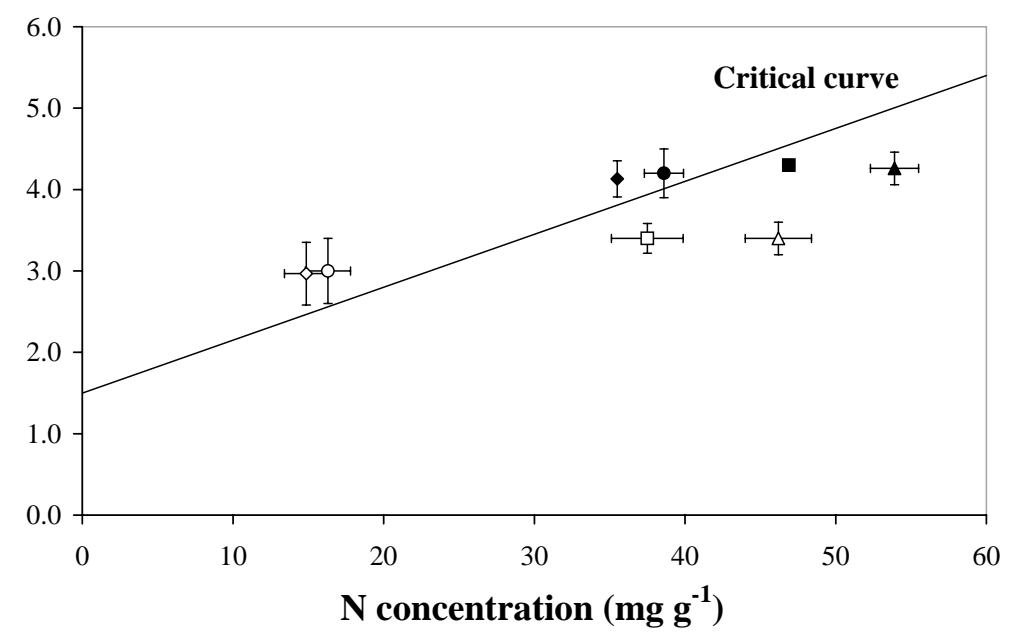

Fig. 1. Relationship between $\mathrm{P}$ and $\mathrm{N}$ concentrations measured on pure stands for ryegrass laminae $(\bigcirc, \bullet)$ and laminae + sheaths $(\diamond$, white clover folioles $(\triangle, \boldsymbol{\Delta})$ and folioles + petioles $(\square, \boldsymbol{\square})$ for N0 (open symbol) and N1 (solid symbol) treatments $\left(\mathrm{mg} \mathrm{g}^{-1}\right)$; (mean \pm S.E., $n=3$ ). The critical curve indicates the optimum P concentration: $\mathrm{P} \%_{\text {optimum }}=0.15+0.065 \mathrm{~N} \%_{\text {measured }}$ (Duru and Thélier-Huché, 1997). 
Table 3

Proportion of white clover in dry matter

\begin{tabular}{|c|c|c|c|c|c|c|c|c|c|c|c|}
\hline \multirow[t]{2}{*}{ Treatment } & \multirow{2}{*}{$\begin{array}{l}\text { Number } \\
\text { of cuts } \\
\text { per year }\end{array}$} & \multicolumn{2}{|l|}{1998} & \multicolumn{4}{|l|}{1999} & \multicolumn{4}{|l|}{2000} \\
\hline & & $\begin{array}{l}\text { Autumn } \\
\text { re-growth }\end{array}$ & S.E. & $\begin{array}{l}\text { Spring } \\
\text { growth }\end{array}$ & S.E. & $\begin{array}{l}\text { Summer } \\
\text { re-growth }(\%)\end{array}$ & S.E. & $\begin{array}{l}\text { Spring } \\
\text { growth }\end{array}$ & S.E. & $\begin{array}{l}\text { Summer } \\
\text { re-growth }\end{array}$ & S.E. \\
\hline \multicolumn{12}{|l|}{ No } \\
\hline P0 & 2 & 6.3 & $(0.9)$ & NA & & 8.7 & (3.6) & NA & & NA & \\
\hline $\mathrm{P} 0$ & 3 & 17.8 & (2.7) & 17.4 & (3.6) & 24.4 & (3.4) & 17.1 & $(2.5)$ & 12.3 & $(4.2)$ \\
\hline $\mathrm{P} 1$ & 3 & 27.1 & (4.1) & 24.1 & (2.3) & 43.3 & (2.7) & 16.4 & (2.6) & 16.9 & (3.3) \\
\hline \multicolumn{12}{|l|}{ N1 } \\
\hline P0 & 3 & 4.7 & (1.4) & 0.7 & $(0.2)$ & 6.5 & $(2.5)$ & NA & & NA & \\
\hline $\mathrm{P} 1$ & 3 & 4.1 & (2.3) & 1.7 & $(0.7)$ & 4.4 & (1.3) & NA & & NA & \\
\hline
\end{tabular}

SE: standard error of mean $(n=4)$; NA: clover absent.

There was a significant effect of $\mathrm{P}$ supply on $\mathrm{P}$ concentration for both cuts in 2000. For each harvest date we observed a significant effect of the fraction analysed; average $P$ concentrations measured on the white clover fraction were always lower than those measured on the one without clover. Phosphorus supply resulted in increased herbage $\mathrm{P}$ concentration but had no effect on dry matter production.

In Fig. 2, $\mathrm{P}$ concentration was plotted against $\mathrm{N}$ concentration for both fractions. There was a linear relationship between $\mathrm{N}$ and $\mathrm{P}$ concentrations measured on the non-clover fraction, indicating that $\mathrm{P}$ uptake was regulated by $\mathrm{N}$ uptake; all the points were well above the critical curve. This result confirmed that non-clover species received an excessive $\mathrm{P}$ supply, which resulted in luxury consumption.

Meanwhile, all but two of the experimental points for white clover were located below the critical curve, suggesting that this species grew under a more limited $P$ supply than did the grasses.

In practice, an increased white clover fraction in the sward resulted in a higher herbage $\mathrm{N}$ concentration and a decrease in $\mathrm{P}$ concentration.

\subsection{Phosphorus nutrition indices (PNI)}

Data collected on Gramond field were used to evaluate the validity of the PNI method, by comparing

Table 4

Nitrogen concentration $\left(\mathrm{mg} \mathrm{g}^{-1}\right.$ dry matter)

\begin{tabular}{|c|c|c|c|c|c|c|c|c|c|c|}
\hline \multirow[t]{2}{*}{ Treatments } & \multicolumn{2}{|c|}{$\begin{array}{l}\text { Autumn re-growth } \\
1998\end{array}$} & \multicolumn{2}{|c|}{$\begin{array}{l}\text { Spring growth } \\
1999\end{array}$} & \multicolumn{2}{|c|}{$\begin{array}{l}\text { Summer re-growth } \\
1999\end{array}$} & \multicolumn{2}{|c|}{$\begin{array}{l}\text { Spring growth } \\
2000\end{array}$} & \multicolumn{2}{|c|}{$\begin{array}{l}\text { Summer re-growth } \\
2000\end{array}$} \\
\hline & $\begin{array}{l}\text { White } \\
\text { clover }\end{array}$ & $\begin{array}{l}\text { Non-white } \\
\text { clover }\end{array}$ & $\begin{array}{l}\text { White } \\
\text { clover }\end{array}$ & $\begin{array}{l}\text { Non-white } \\
\text { clover }\end{array}$ & $\begin{array}{l}\text { White } \\
\text { clover }\end{array}$ & $\begin{array}{l}\text { Non-white } \\
\text { clover }\end{array}$ & $\begin{array}{l}\text { White } \\
\text { clover }\end{array}$ & $\begin{array}{l}\text { Non-white } \\
\text { clover }\end{array}$ & $\begin{array}{l}\text { White } \\
\text { clover }\end{array}$ & $\begin{array}{l}\text { Non-white } \\
\text { clover }\end{array}$ \\
\hline \multicolumn{11}{|l|}{ NO } \\
\hline $\mathrm{P} 0$ & $38.2 \mathrm{a}, \mathrm{b}$ & $32.3 \mathrm{~b}$ & $36.2 \mathrm{a}$ & $23.6 \mathrm{~b}$ & $32.4 \mathrm{a}$ & $21.9 \mathrm{~b}$ & $42.6 \mathrm{a}$ & $24.7 \mathrm{~b}$ & $32.6 \mathrm{a}$ & $16.6 \mathrm{~b}$ \\
\hline $\mathrm{P} 1$ & $40 \mathrm{a}, \mathrm{b}$ & $34.2 \mathrm{a}, \mathrm{b}$ & $36.6 \mathrm{a}$ & $23.0 \mathrm{~b}$ & $31.7 \mathrm{a}$ & $21.6 \mathrm{~b}$ & $42.8 \mathrm{a}$ & $24.2 \mathrm{~b}$ & $30.4 \mathrm{a}$ & $15.9 \mathrm{~b}$ \\
\hline \multicolumn{11}{|l|}{$\mathrm{N} 1$} \\
\hline P0 & $42.7 \mathrm{a}$ & $34.1 \mathrm{ab}$ & NA & NA & $33.1 \mathrm{a}$ & $23.0 \mathrm{~b}$ & NA & NA & NA & NA \\
\hline $\mathrm{P} 1$ & $41.8 \mathrm{a}$ & $37.1 \mathrm{ab}$ & NA & NA & $33.8 \mathrm{a}$ & $22.2 \mathrm{~b}$ & NA & NA & NA & NA \\
\hline $\mathrm{N}$ effect & $*$ & & NA & & NS & & NA & & NA & \\
\hline$P$ effect & NS & & NS & & NS & & NS & & NS & \\
\hline Fraction & $* * *$ & & $* * *$ & & $* * *$ & & $* * *$ & & $* * *$ & \\
\hline
\end{tabular}

Figures within one cut followed by the same letter are not significantly different by Bonferronni-test $P<0.001$. Significance of N, P and fraction effect.

${ }^{*} P<0.1 ;$ (NS: not significant); NA: clover absent.

*** $P<0.001$. 
Table 5

Phosphorus concentration $\left(\mathrm{mg} \mathrm{g}^{-1}\right.$ dry matter)

\begin{tabular}{|c|c|c|c|c|c|c|c|c|c|c|}
\hline \multirow[t]{2}{*}{ Treatments } & \multicolumn{2}{|c|}{$\begin{array}{l}\text { Autumn re-growth } \\
1998\end{array}$} & \multicolumn{2}{|c|}{$\begin{array}{l}\text { Spring growth } \\
1999\end{array}$} & \multicolumn{2}{|c|}{$\begin{array}{l}\text { Summer re-growth } \\
1999\end{array}$} & \multicolumn{2}{|c|}{$\begin{array}{l}\text { Spring growth } \\
2000\end{array}$} & \multicolumn{2}{|c|}{$\begin{array}{l}\text { Summer re-growth } \\
2000\end{array}$} \\
\hline & $\begin{array}{l}\text { White } \\
\text { clover }\end{array}$ & $\begin{array}{l}\text { Non-white } \\
\text { clover }\end{array}$ & $\begin{array}{l}\text { White } \\
\text { clover }\end{array}$ & $\begin{array}{l}\text { Non-white } \\
\text { clover }\end{array}$ & $\begin{array}{l}\text { White } \\
\text { clover }\end{array}$ & $\begin{array}{l}\text { Non-white } \\
\text { clover }\end{array}$ & $\begin{array}{l}\text { White } \\
\text { clover }\end{array}$ & $\begin{array}{l}\text { Non-white } \\
\text { clover }\end{array}$ & $\begin{array}{l}\text { White } \\
\text { clover }\end{array}$ & $\begin{array}{l}\text { Non-white } \\
\text { clover }\end{array}$ \\
\hline \multicolumn{11}{|l|}{ No } \\
\hline $\mathrm{P} 0$ & $2.5 \mathrm{c}$ & $4.9 \mathrm{ab}$ & $3.7 \mathrm{a}$ & $4.1 \mathrm{a}$ & $2.9 \mathrm{a}$ & $3.5 \mathrm{a}$ & $3.3 \mathrm{~b}$ & $3.9 \mathrm{ab}$ & $2.3 \mathrm{~b}$ & $3.3 \mathrm{a}, \mathrm{b}$ \\
\hline $\mathrm{P} 1$ & $2.4 \mathrm{c}$ & $4.8 \mathrm{ab}$ & $4.1 \mathrm{a}$ & $4.3 \mathrm{a}$ & $3.1 \mathrm{a}$ & $4.1 \mathrm{a}$ & $4.4 \mathrm{a}$ & $4.4 \mathrm{a}$ & $2.6 \mathrm{ab}$ & $3.5 \mathrm{a}$ \\
\hline \multicolumn{11}{|l|}{ N1 } \\
\hline $\mathrm{P} 0$ & $2.6 \mathrm{c}$ & $5.4 \mathrm{a}$ & NA & NA & $2.9 \mathrm{a}$ & $3.5 \mathrm{a}$ & NA & NA & NA & NA \\
\hline $\mathrm{P} 1$ & $3.1 \mathrm{bc}$ & $5.3 \mathrm{a}$ & NA & NA & $2.8 \mathrm{a}$ & $3.7 \mathrm{a}$ & NA & NA & NA & NA \\
\hline $\mathrm{N}$ effect & $*$ & & NA & & NS & & NA & & NA & \\
\hline P effect & NS & & NS & & NS & & $* * *$ & & $*$ & \\
\hline Fraction & $* * *$ & & $* *$ & & $* * *$ & & $*$ & & $* * *$ & \\
\hline
\end{tabular}

Figures within one cut followed by the same letter are not significantly different by Bonferronni-test $P<0.001$. Significance of N. P and fraction effect NA: clover absent.

* NS: not significant $P<0.1$.

** $P<0.01$.

*** $P<0.001$.

indices calculated for mixed swards or clover free stands, within a wide range of clover contents.

Phosphorus nutrition indices calculated for the mixed sward and the non-clover fraction are presented in Table 6. N supply affected PNI values at the first harvest; P supply affected the PNI values at three out of five harvest dates. For a given treatment and fraction analysed, PNIs were higher for plots supplied with P except for 1998 autumn re-growth.

Irrespective of the fraction analysed and harvest date, the indices were quite high and consistent with soil $\mathrm{P}$ availability levels; they indicated non-limiting

\section{$\mathbf{P}$ concentration $\left(\mathrm{mg} \mathrm{g}^{-1}\right)$}

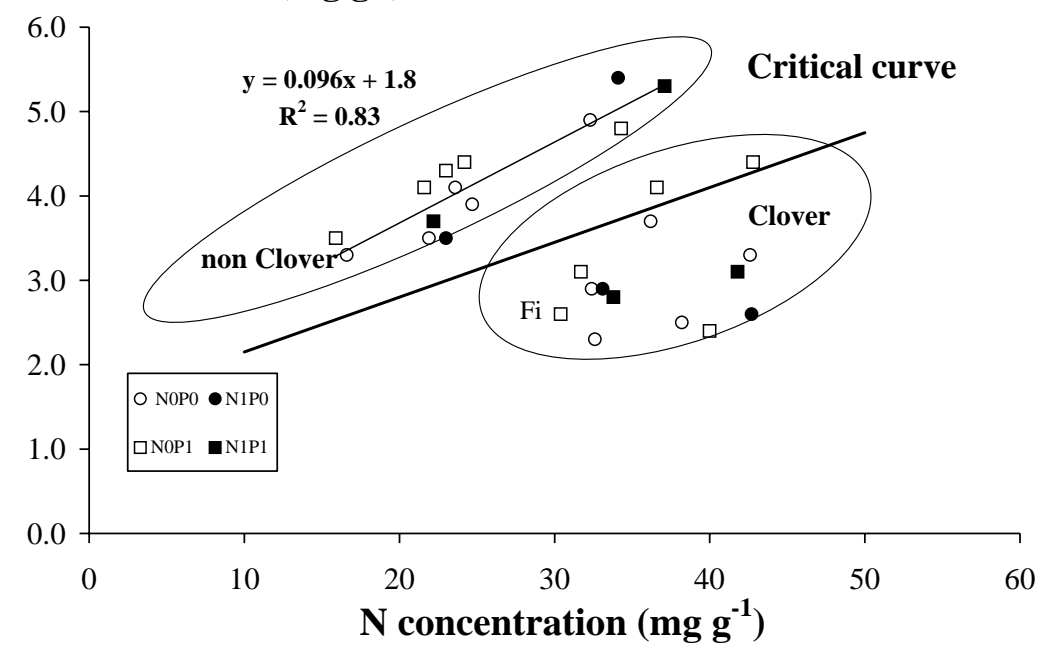

Fig. 2. Relationship between $\mathrm{P}$ and $\mathrm{N}$ concentrations measured for clover and non clover fractions in mixed swards under different $\mathrm{N}$ and $\mathrm{P}$ supply regimes $\left(\mathrm{mg} \mathrm{g}^{-1}\right)$. The critical curve indicates the optimum $\mathrm{P}$ concentration: $\mathrm{P} \%_{\text {optimum }}=0.15+0.065 \mathrm{~N} \%_{\text {measured }}($ Duru and Thélier-Huché, 1997). 
Table 6

Phosphorus nutrition index calculated for mixed sward and non-clover fraction

\begin{tabular}{|c|c|c|c|c|c|c|c|c|c|c|}
\hline \multirow[t]{2}{*}{ Treatments } & \multicolumn{2}{|c|}{$\begin{array}{l}\text { Autumn re-growth } \\
1998\end{array}$} & \multicolumn{2}{|c|}{$\begin{array}{l}\text { Spring growth } \\
1999\end{array}$} & \multicolumn{2}{|c|}{$\begin{array}{l}\text { Summer re-growth } \\
1999\end{array}$} & \multicolumn{2}{|c|}{$\begin{array}{l}\text { Spring growth } \\
2000\end{array}$} & \multicolumn{2}{|c|}{$\begin{array}{l}\text { Summer re-growth } \\
2000\end{array}$} \\
\hline & $\begin{array}{l}\text { Mixed } \\
\text { sward }\end{array}$ & $\begin{array}{l}\text { Non-clover } \\
\text { fraction }\end{array}$ & $\begin{array}{l}\text { Mixed } \\
\text { sward }\end{array}$ & $\begin{array}{l}\text { Non-clover } \\
\text { fraction }\end{array}$ & $\begin{array}{l}\text { Mixed } \\
\text { sward }\end{array}$ & $\begin{array}{l}\text { Non-clover } \\
\text { fraction }\end{array}$ & $\begin{array}{l}\text { Mixed } \\
\text { sward }\end{array}$ & $\begin{array}{l}\text { Non-clover } \\
\text { fraction }\end{array}$ & $\begin{array}{l}\text { Mixed } \\
\text { sward }\end{array}$ & $\begin{array}{l}\text { Non-clover } \\
\text { fraction }\end{array}$ \\
\hline \multicolumn{11}{|l|}{ N0 } \\
\hline $\mathrm{P} 0$ & $122 \mathrm{a}, \mathrm{b}$ & 137 a,b & $126 \mathrm{a}$ & $134 \mathrm{a}$ & $110 \mathrm{~b}$ & 120 a,b & $114 \mathrm{~b}$ & $125 \mathrm{a}, \mathrm{b}$ & $113 \mathrm{~b}$ & 128 a,b \\
\hline $\mathrm{P} 1$ & $109 \mathrm{~b}$ & 129 a,b & $131 \mathrm{a}$ & $142 \mathrm{a}$ & 115 a,b & $140 \mathrm{a}$ & $135 \mathrm{a}, \mathrm{b}$ & $144 \mathrm{a}$ & $122 \mathrm{a}, \mathrm{b}$ & $135 \mathrm{a}$ \\
\hline \multicolumn{11}{|l|}{$\mathrm{N} 1$} \\
\hline $\mathrm{P} 0$ & $140 \mathrm{a}$ & $144 \mathrm{a}$ & NA & NA & $113 \mathrm{~b}$ & $115 \mathrm{a}, \mathrm{b}$ & NA & NA & NA & NA \\
\hline $\mathrm{P} 1$ & $132 \mathrm{a}, \mathrm{b}$ & $135 \mathrm{a}, \mathrm{b}$ & NA & NA & 123 a,b & 126 a,b & NA & NA & NA & NA \\
\hline $\mathrm{N}$ effect & $* * *$ & & NA & & NS & & NA & & NA & \\
\hline $\mathrm{P}$ effect & $* *$ & & NS & & $*$ & & $* * *$ & & NS & \\
\hline Fraction & $* * *$ & & $*$ & & $*$ & & $*$ & & $* *$ & \\
\hline
\end{tabular}

Figures within one cut followed by the same letter are not significantly different by Bonferronni-test $P<0.001$. Significance of N, P and fraction effect.

${ }^{*} P<0.1 ;$ (NS: not significant); NA: clover absent.

** $P<0.01$.

*** $P<0.001$.

P supply for the sward: plants were never deficient in P. However, for each harvest date and treatment, we observed a significant effect of the fraction considered for the index calculation. The average PNIs calculated on the non-clover fraction were always higher than those obtained for the mixed one. For a given sward, when we calculated the difference between
PNI for non clover fraction and PNI for mixed sward, we observed that this value increased with the clover content of the sward (Fig. 3). Consequently, PNI calculated from mixed sward concentrations resulted in an underestimation of the sward P nutrition level when the clover contribution to the sward was more than $20 \%$.

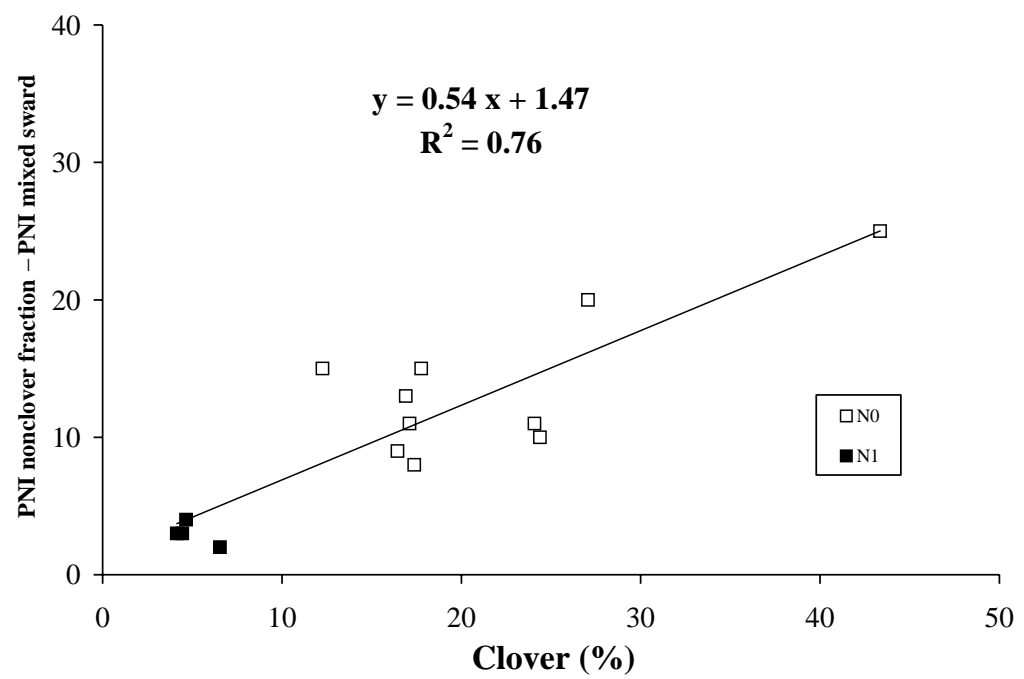

Fig. 3. Difference between the PNI calculated for non-clover fraction and that calculated for mixed sward as related to the sward clover percentage. 


\section{Discussion}

The results will be discussed depending on whether $\mathrm{P}$ is limiting or not, and whether species grow in pure stand or mixed swards.

\subsection{Sward response with an unlimited P supply}

With an ample supply of $\mathrm{P}$, results showed that the ability of rye grass to adjust $\mathrm{P}$ uptake to $\mathrm{N}$ concentration is the same whatever the organs taken for analysis: laminae alone or laminae + sheaths.

On the other hand, white clover's ability to adjust $\mathrm{P}$ uptake to its $\mathrm{N}$ concentration varied according to the organ considered. For a given level of N supply, N concentration decreased when petioles were added to the leaf samples. These results are in accordance with those of Soussana and Arregui (1995), who demonstrated that foliar $\mathrm{N}$ concentration for white clover varies with the mass ratio foliole/petiole. Meanwhile $\mathrm{P}$ concentrations remained constant, suggesting that clover folioles accumulated $\mathrm{N}$ and $\mathrm{P}$ in different proportions from those of grass leaves.

This result can be explained from morphological differences between species. For grasses, laminae show a continuity with sheaths in their tissue composition; they are both metabolic and structural tissues. When both tissues are collected and analysed, the contribution of organs with a low mineral content to the dry weight increases relative to those with a high content and leads to $\mathrm{N}$ and $\mathrm{P}$ dilution with biomass accumulation (Salette and Huché, 1991). For clover however, allocation of functions between folioles and petioles is much more pronounced, the former being composed almost exclusively of metabolic tissues and the latter of sclerenchyma. As a consequence, in pure swards when no competition takes place, clover accumulates $\mathrm{N}$ in folioles, the photosynthetic organs, without accumulating a proportional amount of $\mathrm{P}$.

In a pure sward and for a given $\mathrm{N}$ concentration, $\mathrm{P}$ concentrations measured on whole rye grass plants fall above the critical curve, whereas for clover plants the $\mathrm{P}$ concentrations are slightly below. As these data were obtained without inter-specific competition, two hypotheses can be suggested: either clover experienced $\mathrm{P}$ limitation, since it is less able than grasses to take up $\mathrm{P}$ under similar levels of $\mathrm{P}$ availability, or clover grew under an unlimited $\mathrm{P}$ supply and its critical curve is different from that of grasses. In that case clover would display higher phosphorus use efficiency than grasses. Several arguments favour the second hypothesis. Since a large dose of $\mathrm{P}(250 \mathrm{~kg})$ was supplied each year, the level of soil available $P$ was well above critical levels used for fertiliser recommendation (Poulton et al., 1997), and $P$ concentrations were always above $3.0 \mathrm{mg} \mathrm{g}^{-1}$, the critical $\mathrm{P}$ concentration given in literature for white clover (Mackay et al., 1995). However, we cannot really decide between the two hypotheses since we do not have the critical curve for $\mathrm{P}$ in pure clover stands.

Data obtained in Gramond under unlimited P supply and inter-specific competition showed that responses to treatments were not as significant as they were in pure stands (Tables 1-3). Our results indicate that under mixed swards and for a given tissue fraction, $\mathrm{P}$ concentration was not affected by treatments except for the clover fraction on summer growth 2000. For a given cut, the clover fraction always had an average $\mathrm{P}$ concentration lower than that measured on grasses as reported by Acuña and Wilman (1993). Measured $\mathrm{P}$ concentrations were always above the optimum: $2.8 \mathrm{mg} \mathrm{g}^{-1}$ for rye grass (Bailey et al., 1997b) and $3.0 \mathrm{mg} \mathrm{g}^{-1}$ for white clover (Rangeley and Newbould, 1985).

However, when the experimental points are close to the critical curve (Fig. 2), the data show that the non-clover fraction experienced unlimited $\mathrm{P}$ supply and luxury consumption of $\mathrm{P}$, whereas clover was subjected to a limited $P$ supply, its concentrations falling well below the critical curve. These results confirmed that, although ample $\mathrm{P}$ was provided, white clover in mixed swards grew under conditions of higher competition than it did in pure stands since it is less competitive than grasses for light capture and nutrient acquisition (Mouat, 1983).

\subsection{Sward response under limited P supply}

The question remained, however, as to whether clover displays the same behaviour under limited $\mathrm{P}$ supply. Results in the literature show that when $\mathrm{P}$ is limiting, clover becomes less competitive for $\mathrm{N}$ fixation through limited nodule growth and $\mathrm{N}_{2}$-fixation activity (Haynes and Ludecke, 1981; Høgh-Jensen et al., 2002). Moreover, it is not able to react to $\mathrm{P}$ deficiency by modifying root growth and root 


\section{$P$ concentration $\left(\mathrm{mg} \mathrm{g}^{-1}\right)$}

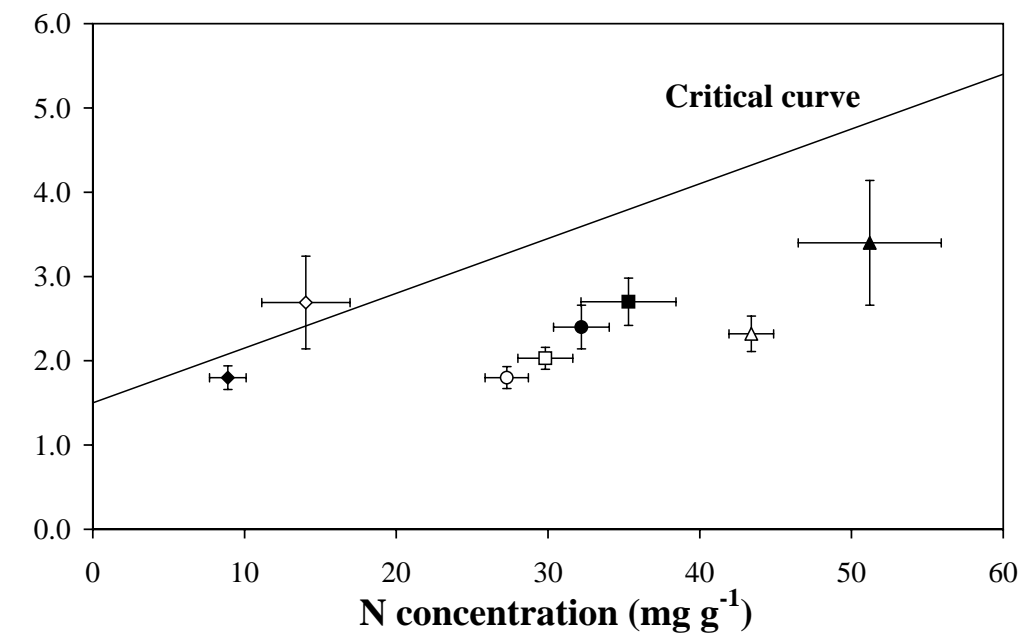

Fig. 4. Relationship between $\mathrm{P}$ and $\mathrm{N}$ concentrations measured on rye grass whole plants $(\diamond, \diamond)$ and white clover folioles $(\triangle$, $\mathbf{\Delta})$, folioles + petioles $(\square, \boldsymbol{\square})$ folioles + petioles + stolons $(\bullet, \bigcirc)$ in pure stand (solid symbols) and mixed swards (open symbols), re-calculation of data from Høgh-Jensen et al. (2001); $\left(\mathrm{mg} \mathrm{g}^{-1}\right)$; (mean \pm S.E., $n=5$ ). The critical curve indicates the optimum $\mathrm{P}$ concentration: $\mathrm{P} \%_{\text {optimum }}$ $=0.15+0.065 \mathrm{~N} \%_{\text {measured }}$ (Duru and Thélier-Huché, 1997).

surface charge as grasses do (Mouat, 1983). On a soil with low to moderate P status, Høgh-Jensen et al. (2001) demonstrated that white clover P concentration in organs declined following $\mathrm{P}$ application to the mixed sward, whereas in pure swards of rye grass and white clover, $\mathrm{P}$ concentration did not increase following $\mathrm{P}$ application. The relationship between $\mathrm{N}$ and $\mathrm{P}$ concentrations measured on their control treatment is presented in Fig. 4. We observe that for both rye grass and white clover monocultures, points fall below the critical curve, indicating that both species experienced limited $\mathrm{P}$ supply during growth, as expected. For clover, when petioles and stolons are taken into account together with folioles, $\mathrm{N}$ and $\mathrm{P}$ dilution accompanies biomass accumulation.

When points for species growing in mixed swards are plotted on the graph, ryegrass moved above the critical curve, indicating that it grew under ample $\mathrm{P}$ supply. Meanwhile, clover is positioned below the curve; more so than for the pure sward, indicating that a less favourable $P$ nutrition level was provided in the mixed sward than in the pure stand. In the mixed sward the contrast between rye grass and clover behaviour is more pronounced.

\subsection{Consequences for $P$ diagnosis in mixed grasslands}

Our data show that the presence of white clover can lead to an underestimation of sward P status (Fig. 3). For fields such as Gramond, which have high P levels diagnosed by PNIs $>100$, the consequences are limited since no $\mathrm{P}$ would be recommended whatever the calculation method used for PNI. However data obtained for limited P supply (Fig. 4) suggest that larger errors could be made when $\mathrm{P}$ is limiting since white clover keeps accumulating $\mathrm{N}$ without accumulating a proportional fraction of $\mathrm{P}$, so PNIs would be more seriously underestimated.

As a consequence when the priority is to optimise dry matter production, in situations with low to moderate $\mathrm{P}$ status we recommend calculating PNIs from mineral contents measured on the non-clover fraction alone, and suggest discarding the white clover fraction before the herbage is prepared for the laboratory; this procedure will prevent overfertilisation.

From data presented in Fig. 1, it can be stated that the risk of underestimating sward $\mathrm{P}$ status will be greater for diagnoses performed on mixed swards of 


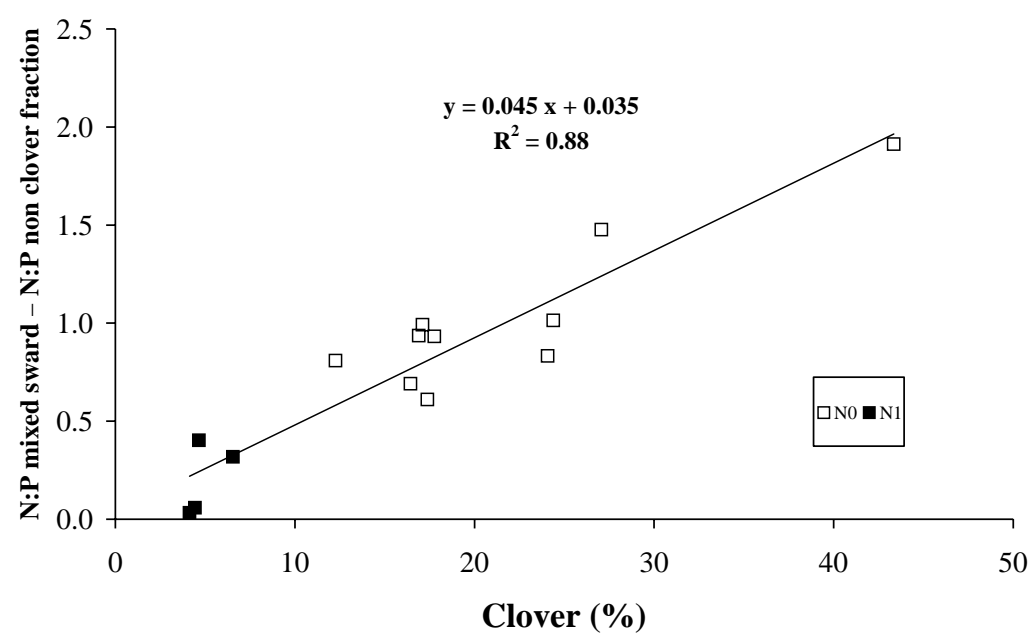

Fig. 5. Difference between the N:P ratio calculated for the mixed sward and that calculated for the non-clover fraction as related to the sward clover percentage.

low bulk and a large foliole contribution to the clover biomass, such as grazed fields.

When the objective is to maintain or increase clover within the herbage in situations with moderate to high $P$ status for grasses, our results reveal practices that encourage clover growth (Table 1). Low residual heights, a frequent cutting regime and absence of $\mathrm{N}$ fertilisation are practices frequently reported to maintain or increase clover content in mixed swards (Barthram et al., 1992). These practices will be more efficient than $P$ fertiliser since there is a risk that $\mathrm{P}$ supply promotes grasses which are more competitive and this results in the disappearance of the clover. Finally, where P status is low, in order to make enough $\mathrm{P}$ available for clover, we have to accept $\mathrm{P}$ luxury consumption for the grasses.

Similar consequences of the presence of white clover are expected when calculating $\mathrm{N}: \mathrm{P}$ ratios as proposed by Koerselman and Meuleman (1996) to indicate the nature of nutrient limitation ( $\mathrm{N}$ vs. P) at community levels (Olde Venterink et al., 2001; Oelmann and Broll, 2002). We used our data to compare N:P ratios calculated on mixed swards and those of the non-clover fraction. We observed that the presence of white clover in the fraction analysed increased the mixed sward N:P ratio. For a given sward, when we calculated the difference between N:P for mixed sward and N:P for non clover fraction, we observed that this value increased with the proportion of white clover in the sward (Fig. 5). As an example, the threshold values 16 and 14 proposed by Koerselman and Meuleman (1996) to diagnose $\mathrm{P}$ limitation (N:P $>16), \mathrm{N}$ and $\mathrm{P}$ co-limitation $(14<\mathrm{N}: \mathrm{P}<16)$ and $\mathrm{N}$ limitation $(\mathrm{N}: \mathrm{P}<14)$ on clover-free swards, would become 18 and 16 with $40 \%$ of white clover in the sward, resulting in misinterpretation of the nature of the nutrient limitation.

Finally, one can expect that similar results would be obtained for $\mathrm{K}$ unless clover can compete with grasses for K better than for P (Høgh-Jensen et al., 2001).

The question remains as to what extent variations observed in the presence of white clover can be extrapolated to other legumes which often occur with grasses in natural or sown grasslands.

\section{Conclusions}

With an unlimited $\mathrm{P}$ supply, in pure swards and when folioles and petioles are analysed together, clover nutritional status differs little from that of grasses. When clover is present in a natural sward, it experiences a lower nutritional $\mathrm{P}$ status than the grass fraction since it has a lower capacity for light capture and $\mathrm{P}$ acquisition than the companion species.

With a limited $\mathrm{P}$ supply, differences in response pattern between clover and grass are more pronounced for pure stands as well as for mixed swards. Clover is 
less able to adjust its $\mathrm{P}$ concentration to that of $\mathrm{N}$ due to its smaller capacity to adapt to low $\mathrm{P}$ availability. As a consequence it becomes even less competitive.

These results imply limitations in the use of diagnostic systems based on relative concentrations when the herbage contains a large proportion of white clover. Whatever the index used for diagnosis (PNI or N:P ratio), mineral contents measured on mixed swards could lead to a substantial underestimation of sward $P$ status. Therefore, we suggest basing diagnosis on the non-clover fraction to avoid excessive $\mathrm{P}$ recommendations when PNIs are used.

\section{Acknowledgements}

We thank Dr. G. Lemaire for helpful discussion and critical reading of the manuscript, J. Foucras (Chambre d'Agriculture de l'Aveyron), for his help with field experimentation. This work was partially funded by the European Commission through VISTA project (EVK2-CT-2002-00168).

\section{References}

Acuña, G.H., Wilman, D., 1993. Some effects of added phosphorus on perennial rye-grass white clover swards. Grass For. Sci. 48, 416-420.

Aerts, R., Chapin, F.S., 2000. The mineral nutrition of wild plants revisited: a re-evaluation of processes and patterns. Adv. Ecol. Res. 30, 2-67.

Bailey, J.S., Beattie, J.A.M., Kilpatrick, D.J., 1997a. The diagnosis and recommendation system (DRIS) for diagnosing the nutrient status of grassland swards: I Model establishment. Plant and Soil 197, 127-135.

Bailey, J.S., Cushanahan, A., Beattie, J.A.M., 1997b. The diagnosis and recommendation system (DRIS) for diagnosing the nutrient status of grassland swards: II Model calibration and validation. Plant and Soil 197, 137-147.

Bailey, J.S., Dills, R.A., Foy, R.H., Patterson, D., 2000. The diagnosis and recommendation system (DRIS) for diagnosing the nutrient status of grassland swards: III Practical applications. Plant and Soil 222, 255-262.

Barthram, G.T., Grant, S.A., Elston, D.A., 1992. The effects of sward height and nitrogen fertilizer application on changes in sward composition, white clover growth and the stock carrying capacity of an upland perennial ryegrass/white clover sward grazed by sheep for four years. Grass For. Sci. 47, 326-341.

Brown, D., 1954. Methods of surveying and managing vegetation. Bull. Commonwealth Bureau of Pastures and Crops. Farmham Royal, vol. 42, p. 233.
Duru, M., Ducrocq, H., 1997. A nitrogen and phosphorus herbage nutrient index as a tool for assessing the effect of $\mathrm{N}$ and $\mathrm{P}$ supply on the dry matter yield for permanent pastures. Nut. Cycl. Agro. 47, 59-69.

Duru, M., Thélier-Huché, L., 1997. N and P-K status of herbage: use for diagnosis of grasslands, in: INRA (Eds.), Diagnostic Procedures for Crop N Management and Decision Making, pp. 125-138.

Haynes, R.J., Ludecke, T.E., 1981. Yield, root morphology and chemical composition of two pasture legumes as affected by lime and phosphorus applications to an acid soil. Plant and Soil 62, 241-254.

Høgh-Jensen, H., Vibeke, F., Schjoerring, J.K., 2001. Regrowth and nutrient composition of different plant organs in grass-clover canopies as affected by phosphorus and potassium availability. Ann. Bot. 88, 153-162.

Høgh-Jensen, H., Schjoerring, J.K., Soussana, J.F., 2002. The influence of phosphorus deficiency on growth and nitrogen fixation of white clover plants. Ann. Bot. 90, 745-753.

Koerselman, W., Meuleman, A.F.M., 1996. The vegetation N:P ratio: a new tool to detect the nature of nutrient limitation. J. Appl. Ecol. 33, 1441-1450.

Lemaire, G., Gastal, F., Salette, J., 1989. Analysis of the effect of $\mathrm{N}$ nutrition on dry matter yield of a sward by reference to potential yield and optimum $\mathrm{N}$ content. In: Proceedings of the XVI International Grassland Congress, Nice, pp. 179180.

Mackay, A.D., Saggar, S., Trolove, S.N., Lambert, M.G., 1995. Use of an unsorted pasture sample in herbage testing for sulphur, phosphorus and nitrogen. N.Z. J. Agric. Res. 38, 483-493.

Mouat, M.C.H., 1983. Competitive adaptation by plants to nutrient shortage through modification of root growth and surface charge. N.Z. J. Agric. Res. 26, 327-332.

Oelmann, Y., Broll, G., 2002. Nutrient dynamics in wet grassland under different management in Northwest-Germany. Grassland Sci. Europe, 718-719.

Olde Venterink, H., van der Vliet, R.E., Wassen, M.J., 2001. Nutrient limitation along a productivity gradient in wet meadows. Plant and Soil 234, 171-179.

Olsen. S.R., Cole, C.V., Watanabe, F.S., Dean, L.A., 1954. Estimation of available phosphorus in soils by extraction with sodium bicarbonate. USDA Circ. 939. US Gov. Print. Office, Washington, DC.

Pinkerton, A., Randall, P.J., 1994. Internal phosphorus requirement of six legumes and two grasses. Aust. J. Exp. Agric. 34, 373379.

Poulton, P.R., Tuney, H., Johnston, A.E., 1997. Comparison of fertilizer phosphorus recommendations in Ireland and England and Walles. In: Tunney, H., Carton, O.T., Books P.C., Johnston, A.E. (Eds.), Phosphorus Loss from Soil to Water. CAB International, Wallingford, pp. 177-203.

Rangeley, A., Newbould, P., 1985. Growth response to lime and fertilizers and critical concentrations in herbage of white clover in Scottish hill soils. Grass For. Sci. 40, 265-277.

Salette, J., Huché, L., 1991. Diagnostic de l'état de nutrition minérale d'une prairie par l'analyse du végétal: principes, mise en œuvre, exemples. Fourrages 125, 3-18. 
Sinclair, A.G., Morrison, J.D., Smith, L.C., Doods, K.G., 1996. Effects and interactions of phosphorus and sulphur on a mown white clover/ryegrass sward. Part 2. Concentrations and ratios of phosphorus, sulfur, and nitrogen in clover herbage in relation to balanced plant nutrition. N.Z. J. Agric. Res. 39, 435-445.

Soussana, J.F., Arregui, M.C., 1995. Impact de l'association sur le niveau de nutrition azotée et la croissance du ray-grass anglais et du trèfle blanc. Agronomie 15, 81-96.

Statistix, 1996. Version 4.1, Analytical software, Tallahassee, Fl, $329 \mathrm{p}$.

Thélier-Huché, L., Farruggia, A., Castillon, P., 1999. L'analyse d'herbe: un outil pour le pilotage de la fertilisation phosphatée et potassique des prairies naturelles et temporaires. Comifer, Paris, 31p.
Tunney, H., Breeuwsma, A., Withers, P.J.A., Ehlert, P.A.I., 1997. Phosphorus fertilizer strategies: present and future. In: Tunney, H., Carton, O.T., Books P.C., Johnston, A.E. (Eds.), Phosphorus Loss from Soil to Water. CAB International, Wallingford, pp. 177-203.

Van Veldhoven, P.P., Mannaerts, G.P., 1987. Inorganic and organic phosphate measurements in the nanomolar range. Anal. Biochem. 161, 45-48.

Walworth, J.L., Sumner, M.E., Isaac, R.A., Plank, C.O., 1986. Preliminary DRIS norms for alphalpha in the southeastern United States and a comparison with midwestern norms. Agron. J. 78, 1046-1052.

Whitehead, D.C., 1995. Grassland Nitrogen. CAB International, Wallingford, $397 \mathrm{pp}$. 